\title{
EFEK CONTRAST BATH DIBANDINGKAN ICE BATH PADA PEMULIHAN KEKUATAN OTOT PEMAIN FUTSAL
}

\author{
Kurnia Putri Utami*, Azumah, Ali Multazam, Nikmatur Rosidah \\ Program Studi Fisioterapi, Fakultas Ilmu Kesehatan, Universitas Muhammadiyah Malang \\ *Korespondensi: kurniaputri01@umm.ac.id
}

\begin{abstract}
ABSTRAK
Pemain futsal dituntut memiliki komponen kondisi fisik yang baik terutama kekuatan otot. Bermain dengan intensitas tinggi dapat mengakibatkan kelelahan otot dan dapat mengurangi performa pemain. Secara fisiologis, kondisi pemain akan kembali seperti semula setelah beristirahat. Namun, pemain dituntut untuk secepatnya pulih dari kelelahan sehingga dibutuhkan metode pemulihan yang tepat salah satunya menggunakan hidroterapi, yaitu contrast bath dan ice bath. Metode ini sudah banyak diaplikasikan pada atlet, tetapi penelitian secara komprehensif tentang efektivitas kedua metode ini masih terbatas. penelitian ini dilakukan untuk mengetahui perbandingan pengaruh contrast bath dan ice bath terhadap pemulihan kekuatan otot pada pemain futsal. Jenis penelitian ini adalah Quasi Eksperimental dengan model eksperimen two group pretest-posttest menggunakan tekhnik purposive sampling. Responden dalam penelitian ini adalah siswa SMA yang mengikuti ekstrakurikuler futsal yang dikelompokkan dalam grup contrast bath dan grup ice bath. Pengukuran kekuatan otot dilakukan menggunakan Leg dynamometer test. Berdasarkan hasil analisis statistic Mann-Whitney U-Test, tidak terdapat perbedaan bermakna pada pengaruh contrast bath dan ice bath terhadap pemulihan kekuatan otot $(p<0,05)$. Tidak terdapat perbedaan pengaruh contrast bath dan ice bath terhadap pemulihan kekuatan otot pada pemain futsal SMA kota Malang.
\end{abstract}

Kata Kunci: Contrast Bath, Ice Bath, Kekuatan Otot, Futsal

\section{PENDAHULUAN}

Futsal merupakan kata yang digunakan secara Internasional untuk permainan sepak bola di dalam ruangan. Kata futsal berasal dari kata futbol atau futebol (dari bahasa Spanyol atau Portugal yang artinya permainan sepakbola) dan salon atau sala (dari bahasa Prancis atau Spanyol yang artinya dalam ruangan) (Murhananto, 2008). Dalam olahraga futsal dibutuhkan daya tahan atau kondisi fisik yang sangat baik. Salah satu komponen kondisi fisik yang dibutuhkan pemain futsal adalah kekuatan otot.

Menurut Anggoro (2015), kekuatan otot adalah kemampuan otot untuk menghasilkan tegangan dan resultan gaya berdasarkan permintaan pada otot. Tanpa otot yang kuat, maka power dan agility juga akan menurun. Selain itu, kekuatan otot dan jaringan yang baik akan mencegah dari cedera. Semakin kuat otot dan jaringan, maka tubuh akan mampu mengatasi beban pada saat pertandingan. Kekuatan otot yang baik akan membantu atlet untuk mengatasi tekanan saat bertanding. Sehingga atlet akan lebih cekatan dalam melakukan gerakangerakan yang diperlukan dalam cabang olahraganya.

Kelelahan otot dapat disebabkan karena intensitas bermain yang tinggi dan dapat menurunkan kondisi fisik pemain (Izzudin, 2018). Kelelahan otot merupakan suatu kondisi yang dihasilkan dari kontraksi otot yang kuat dan berkepanjangan, kelelahan otot dapat terjadi pada semua orang seperti lansia, dewasa, remaja atau bahkan anak- anak, 
didalam metode pengukuran, kelelahan otot bisa dikatakan sebagai waktu terjadinya kelelahan otot, penundaan pemulihan otot, ataupun penurunan kekuatan otot. Otot yang lelah adalah otot yang tidak dapat berkontraksi (Sayono, 2011). Kelelahan otot dalam latihan singkat yang maksimum maupun saat bertanding berhubungan dengan penurunan oksigen dan peningkatan kadar asam laktat dalam darah dan otot yang akan mengganggu keseimbangan cairan dan elektrolit dalam tubuh, menyebabkan penurunan kekuatan dan kecepatan kontraksi atau pergerakan otot (Simon, 2017)

Data English Championship soccer matches menunjukkan bahwa adanya penurunan kekuatan otot pada akhir pertandingan yang disebabkan adanya kelelahan (Greig et al, 2010). Setelah melakukan latihan spesifik, terjadi penurunan kekuatan otot (Oliver et al, 2007). Penurunan kekuatan otot terbesar adalah pada saat gerakan drop jump yang menunjukkan pengaruh kekuatan otot yang berkurang ketika lelah. Sistem permainan 90 menit yang terdiri dari dua periode yang dipisahkan oleh istirahat 15 menit menyebabkan terjadinya kelelahan selama dan setelah pertandingan yang mempengaruhi penurunan kekuatan otot quadriceps (Robineau et al, 2012)

Kegiatan pemulihan menjadi hal yang sangat penting, maka dari itu metode pemulihan harus dipilih secara tepat. Sesuai dengan perkembangan jaman, banyak metode pemulihan saat ini digunakan dalam pengembangan olahraga. Salah satunya adalah teknik pemulihan yang menggunakan air sebagai medianya. Teknik pemulihan ini disebut hidroterapi (Reny, 2015). Hydrotherapy yang dimaksud antara lain contrast bath dan ice bath. Kedua metode ini telah banyak diaplikasikan pada atlet dan menjadi metode popular di dunia olahraga.

Contrast bath merupakan modalitas termal merendam bagian tubuh secara bergantian dalam air panas dan air dingin dengan suhu, waktu dan durasi tertentu untuk meningkatkan kekuatan otot, mengurangi nyeri otot dan menyembuhkan kerusakan otot (Bieuzen et al, 2013). Perendaman air panas dan dingin dilakukan dengan suhu panas $38^{\circ} \mathrm{C}$ dan suhu dingin $15^{\circ} \mathrm{C}$ dengan waktu 10 menit. Perendaman contrast bath akan menyebabkan pembuluh darah mengalami kontraksi dan relaksasi sehingga aksi pemompaan terjadi. Aksi pemompaan ini akan menyediakan oksigen dan nutrisi dengan meningkatkan aliran darah agar pemulihan setelah permainan berlangsung cepat (Kim J, et al,2020)

Ice bath merupakan perendaman dengan menggunakan air dingin dengan suhu $10^{\circ} \mathrm{C}$ dengan waktu 15 menit (Ingram et al, 2009). Perendaman air dingin akan menginduksi vasokonstriksi perifer (Peiffer et al, 2009). Vasokonstriksi ini dapat mengurangi permeabilitas pembuluh kapiler, seluler dan limfatik yang akan mencegah pembengkakan dari difusi cairan (Eston \& Peters, 1999), sehingga membatasi respon inflamasi akut setelah kerusakan otot akibat latihan. Ice bath juga mengurangi nyeri, sebagai anti inflamasi, relaksasi otot, relaksasi psikologi, menghambat kerusakan otot, mengurangi edema serta menurunkan suhu jaringan (Rifan, 2014).

\section{METODE PENELITIAN}

Jenis penelitian ini adalah Quasi Eksperimental dengan model eksperimen two group pretest-posttest. Pada penelitian ini, sample dibagi menjadi 2 kelompok dengan 2 perlakuan yang berbeda selama 3 minggu. Kelompok 1 adalah kelompok sample yang diberikan contrast bath dan kelompok 2 adalah kelompok sample yang diberikan ice bath. Sebelum diberikan perlakuan, pada masing-masing kelompok diberikan pretest dan setelah diberikan perlakuan kedua kelompok diberikan posttest. Kelompok 1 merendam tubuh bagian bawah (ekstremitas bawah) kedalam bath berisi air dengan suhu $15^{\circ} \mathrm{C}$ selama 10 
menit dan air bersuhu $38^{\circ} \mathrm{C}$ selama 10 menit secara bergantian. Kelompok II merendam tubuh bagian bawah (ekstremitas bawah) kedalam bath berisi air dengan suhu $15^{\circ} \mathrm{C}$ selama 15 menit.

Responden dalam penelitian ini adalah Pemain futsal SMA Negeri 8 Malang yang berjumlah 30 orang. Alat ukur yang digunakan untuk menilai kekuatan otot adalah Leg Dynamometer. Uji normalitas dilakukan menggunakan Shapiro-wilk karena jumlah sampel kurang dari 50 orang. Uji Wilcoxon dilakukan untuk mengetahui pengaruh masing-masing perlakuan dan selanjutnya Uji Mann-Whitney dilakukan untuk membandingan pengaruh kedua perlakuan. Proses Analisa data dilakukan dengan menggunakan program SPSS

\section{HASIL}

\section{A. Karakteristik Responden}

1. Karakteristik responden berdasarkan usia

Responden pada penelitian ini merupakan pemain futsal SMAN 8 Kota Malang dengan jumlah responden sebanyak 30 orang. Berdasarkan usia didapatkan hasil sebagai berikut :

Tabel 1. Karakteristik responden berdasarkan usia

\begin{tabular}{ccc}
\hline Usia & Jumlah & Presentase \\
\hline 16 tahun & 25 & $83 \%$ \\
17 tahun & 4 & $14 \%$ \\
18 tahun & 1 & $3 \%$ \\
\hline Total & $\mathbf{3 0}$ & $\mathbf{1 0 0 \%}$
\end{tabular}

(Sumber : Data Primer 2019)

Berdasarkan tabel di atas menunjukkan bahwa karakteristik responden berdasarkan usia 16 tahun berjumlah 25 dengan presentase $83 \%$, usia 17 tahun berjumlah 4 orang dengan presentase $14 \%$ dan 18 tahun berjumlah 1 orang dengan presentase $3 \%$. Jadi dapat disimpulkan bahwa responden terbanyak terdapat pada umur 16 tahun.

2.Karakteristik responden berdasarkan indeks massa tubuh (IMT)

Tabel 2. Karakteristik responden berdasarkan indeks massa tubuh

\begin{tabular}{|c|c|c|c|}
\hline Kategori & IMT $\left(\mathrm{kg} / \mathrm{m}^{2}\right)$ & $\mathbf{n}$ & $\%$ \\
\hline Kurus & $<18,5$ & 12 & $40 \%$ \\
\hline Normal & $\geq 18,5-<24,9$ & 17 & $57 \%$ \\
\hline Obesitas & $\geq 27$ & 1 & $3 \%$ \\
\hline \multicolumn{2}{|r|}{ Total } & 30 & $100 \%$ \\
\hline
\end{tabular}

Berdasarkan tabel diatas menunjukkan bahwa karakteristik responden berdasarkan IMT yang memiliki kategori kurus $\left(<18,5 \mathrm{~kg} / \mathrm{m}^{2}\right)$ berjumlah 12 orang dengan presentase $40 \%$, memiliki kategori normal $(\geq 18,5$ - < $24,9 \mathrm{~kg} / \mathrm{m}^{2}$ ) berjumlah 17 orang dengan presentase $57 \%$, dan memiliki kategori obesitas $\left(\geq 27 \mathrm{~kg} / \mathrm{m}^{2}\right)$ berjumlah 1 orang dengan presentase $3 \%$. Jadi dapat disimpulkan berdasarkan klasifikasi indeks massa tubuh terbanyak pada kategori normal.

B. Rata-rata nilai leg dynamometer test sebelum dan sesudah intervensi contrast bath dan ice bath

Rata-rata nilai leg dynamometer test sebelum dilakukan intervensi contrast bath dan ice bath dengan rata-rata nilai leg dynamometer setelah dilakukan intervensi contrast bath dan ice bath didapatkan hasil sebagai berikut: 
Tabel 3. Rata-rata nilai leg dynamometer test sebelum dan sesudah intervensi contrast bath

\begin{tabular}{|c|c|c|}
\hline & Nilai Leg & Nilai leg \\
\hline & $\begin{array}{l}\text { Dynamometer } \\
\text { test }\end{array}$ & $\begin{array}{l}\text { DynamometerSelisih } \\
\text { test }\end{array}$ \\
\hline & Pre-test & Post-test \\
\hline mean & 101,67 & 109,67 \\
\hline
\end{tabular}

(Sumber : Data Primer, 2019)

Berdasarkan tabel 3 didapatkan hasil bahwa terdapat 15 responden contrast bath dan 15 responden ice bath. Diketahui rata-rata nilai leg dynamometer test sebelum diberi intervensi contrast bath memiliki nilai 101,67 dan rata-rata nilai leg dynamometer test sesudah diberikan intervensi contrast bath memiliki nilai 109,67 dengan selisih 8. Hasil ini menunjukkan terdapat peningkatan kekuatan otot setelah diberikan intervensi contrast bath.

Tabel 4. Rata-rata nilai leg dynamometer test sebelum dan sesudah intervensi ice bath

\begin{tabular}{llll}
\hline \multirow{2}{*}{$\begin{array}{l}\text { Responden } \\
\end{array}$} & $\begin{array}{l}\text { Nilai leg } \\
\text { Dynamometer } \\
\text { test }\end{array}$ & $\begin{array}{l}\text { Nilai leg } \\
\text { Dynamometer } \\
\text { test }\end{array}$ \\
\cline { 2 - 3 } Pre-test & Post-test & \\
\hline mean & 99 & 107,33 & 8.33 \\
\hline
\end{tabular}

(Sumber : Data Primer, 2019)

Berdasarkan tabel 4 didapatkan hasil rata-rata nilai leg dynamometer test sebelum diberikan intervensi ice bath memiliki nilai 99 dan rata-rata nilai leg dynamometer test sesudah diberikan intervensi ice bath memiliki nilai 107,33 dengan selisih 8,33. Hasil ini menunjukan adanya peningkatan kekuatan otot setelah pemberian ice bath.

\section{Perbandingan pengaruh contrast bath} dan ice bath terhadap pemulihan kekuatan otot pada pemain futsal kota Malang

\section{Uji Normalitas}

Uji normalitas yang digunakan pada penelitian ini adalah shapiro-wilk yaitu data berdistribusi normal apabila nilai $\mathrm{p}$ $>0,05$ dan data berdistribusi tidak normal apabila nilai $\mathrm{p}<0,05$. Uji normalitas shapiro-wilk data pre-test posttest contrast bath dan ice bath adalah sebagai berikut :

Tabel 5. Uji normalitas data pre-test dan post-test kelompok contrast bath dan ice bath

\begin{tabular}{|c|c|c|c|}
\hline & \multicolumn{2}{|c|}{ Nilai sig.2 Tailed } & Nilai $\alpha$ \\
\hline $\begin{array}{l}\text { Kelompok } \\
\text { Perlakuan }\end{array}$ & Pretest & Postest & \\
\hline Contrast Bath & 0.001 & 0.001 & 0.05 \\
\hline Ice Bath & 0.002 & 0.006 & 0.05 \\
\hline
\end{tabular}

$$
\text { Uji shapiro-wilk : } \alpha=\text { nilai }
$$

kesalahan maksimal

(Sumber : Data primer, 2019)

Hasil uji normalitas dengan shapiro-wilk menggunakan SPSS menunjukkan nilai signifikasi pada pretest dan posttest intervensi contrast bath adalah 0,001 $(\mathrm{p}<0,05)$ dan $0,001(\mathrm{p}<0,05)$, sedangkan pada pretest dan posttest itervensi ice bath adalah 0,002 $(\mathrm{p}<0,05)$ dan 0,006 $(\mathrm{p}<0,05)$. Berdasarkan tabel 5 dapat disimpulkan bahwa data berdistribusi tidak normal.

\section{Hasil Uji Pengaruh Pemberian Intervensi Contrast Bath Terhadap Pemulihan Kekuatan Otot}

Analisa data pada penelitian ini menggunakan uji wilcoxon karena data berdistribusi tidak normal, untuk 
mengetahui pengaruh pemberian intervensi contrast bath terhadap kekuatan otot.

Tabel 6. Uji pengaruh data pre-test dan post-test kelompok contrast bath

\begin{tabular}{llcc}
\hline & N & P & $\boldsymbol{\alpha}$ \\
\hline $\begin{array}{l}\text { Pretest-postest } \\
\text { contrast bath }\end{array}$ & 15 & 0,002 & 0,05 \\
& & &
\end{tabular}

\section{Total} 15

Uji Wilcoxon: $\mathrm{N}=$ jumlah responden ; $\mathrm{P}=$ nilai hasil data $; \alpha=$ nilai kesalahan maksimal

(Sumber : Data primer, 2019)

Berdasarkan tabel 6 didapatkan hasil dengan uji wilcoxon nilai $\mathrm{P}=0,002$ $(\mathrm{p}<0,05)$. Jadi dapat disimpulkan bahwa ada pengaruh signifikan pemberian contrast bath terhadap pemulihan kekuatan otot pada pemain futsal kota Malang.

\section{Hasil Uji Pengaruh Pemberian Intervensi Ice Bath Terhadap Pemulihan Kekuatan Otot}

Analisa data pada penelitian ini menggunakan uji wilcoxon karena data berdistribusi tidak normal, untuk mengetahui pengaruh pemberian intervensi ice bath terhadap kekuatan otot.

Tabel 7. Uji pengaruh data pre-test dan post-test ice bath

\begin{tabular}{lccc}
\hline & N & P & $\boldsymbol{\alpha}$ \\
\hline $\begin{array}{l}\text { Pretest-postest } \\
\text { ice bath }\end{array}$ & 15 & 0,003 & 0,05 \\
Total & 15 & & \\
\hline
\end{tabular}

Uji Wilcoxon: $\mathrm{N}=$ jumlah responden ; $\mathrm{P}$ $=$ nilai hasil data $; \alpha=$ nilai kesalahan maksimal

(Sumber : Data primer, 2019)
Berdasarkan tabel 7 didapatkan hasil analisa statistik dengan uji wilcoxon nilai $\mathrm{P}=0,003 \quad(\mathrm{p}<0,05)$. Jadi dapat disimpulkan bahwa ada pengaruh signifikan pemberian ice bath terhadap pemulihan kekuatan otot pada pemain futsal Kota Malang.

\section{Hasil Uji Perbandingan Pengaruh Contrast Bath Dan Ice Bath Terhadap} Pemulihan Otot

Pada penelitian ini dilakukan uji MannWhitney $U$ untuk melihat perbandingan pengaruh contrast bath dan $\mathrm{k}$ ice bath terhadap pemulihan kekuatan otot.

Tabel 8. Uji Perbandingan Kelompok Contrast Bath dan Ice Bath

\begin{tabular}{cccc}
\hline Kelompok & $\mathbf{N}$ & $\begin{array}{c}\text { Asymp.Sig } \\
\text { (2-Tailed) }\end{array}$ & $\boldsymbol{\alpha}$ \\
Contrast Bath & 15 & 0,766 & 0,05 \\
Ice Bath & 15 & & \\
\hline
\end{tabular}

Uji Mann-Whitney $\boldsymbol{U}: \alpha=$ nilai kesalahan maksimal

(sumber : Data primer, 2019)

Berdasarkan table 8 didapatkan nilai Asymp Sig (2-tailed) pada kelompok contrast bath dan ice bath adalah 0,766 ( $\mathrm{p}<0,05$ ). Jadi dapat disimpulkan bahwa tidak ada perbedaan pengaruh contrast bath dan ice bath terhadap pemulihan kekuatan otot pada pemain futsal di SMA Negeri 8 kota Malang. 


\section{PEMBAHASAN}

\section{Karakteristik Responden berdasarkan usia}

Hasil penelitian pada kelompok contrast bath dengan kelompok ice bath pada siswa SMA Negeri 8 malang yang mengikuti ekstrakurikuler futsal menunjukkan bahwa usia 16 tahun merupakan usia responden yang paling banyak. Periode masa remaja didefinisikan sebagai suatu periode dalam perkembangan yang dijalani seseorang yang terbentang sejak berakhir masa kanak-kanak sampai datangnya awal masa dewasa yakni rentang usia 11-13 tahun sampai 18-20 tahun (Al Fajr, 2019). Pada usia remaja akan terjadi peningkatan kekuatan sebesar 5-10\% tenaga cadangan dan kekuatan fisik lebih besar dibanding usia lebih tua. Windiyatno (2015) mengatakan dalam penelitiannya bahwa pada umur 18 tahun memiliki tingkat kekuatan otot yang lebih tinggi daripada umur 16 tahun dan 17 tahun. Manfaat kekuatan otot yaitu : 1. Melatih kekuatan dan daya tahan dapat menperbanyak kekuatan dalam kegiatan, Secara umum, dengan tingkat kekuatan otot sedikit akan gampang merasakan lelah saat beraktifitas. 2. Menghindari dari cidera, karena melatih kekuatan dan daya tahan otot dapat membuat sel tendon, ligamen dan tulang rawan lebih kuat untuk mencegah cedera 3 . Mengurangi kadar lemak didalam tubuh. 4. mencegah degenerasi otot. 5. Meningkatkan kualitas hidup karena dapat menambah energi, mennghindari cedera, dan lebih mudah melakukan kegiatan sehari-hari (Wasisto, 2016).

\section{Karakteristik Berdasarkan Indeks Massa Tubuh (IMT)}

Hasil penelitian pada kelompok contrast bath dengan kelompok ice bath pada siswa SMA Negeri 8 malang yang mengikuti ekstrakurikuler futsal memiliki IMT paling banyak dengan kategori berat badan normal. IMT normal atau lebih diasumsikan bahwa komposisi tubuh mengandung banyak massa tubuh tanpa lemak (fat free weight/lean body mass). Komponen massa tubuh tanpa lemak meliputi massa otot, tulang, kulit, jaringan bukan lemak dan jaringan tubuh lain. Massa otot yang besar akan mempengaruhi kekuatan otot (Setiowati, 2014). indeks massa tubuh berkolerasi negatif dengan kekuatan otot tungkai per berat badan (Miyatake et al, 2012). Dalam kategori status indeks massa tubuh menurut Depkes RI, setiap orang dengan IMT antara 25 dan 27 akan tergolong kelebihan berat badan dan setiap orang dengan >27 akan diklasifikasikan sebagai obesitas. Namun, orang yang memiliki aktifitas fisik berlebih mungkin memiliki indeks massa tubuh tinggi karena peningkatan otot daripada lemak tubuh (Ningrum et al, 2017). Penelitian yang dilakukan oleh Valenzuela et al (2020) menunjukkan hasil kualitas otot yang buruk pada kelompok obesitas. Kualitas otot yang dimaksud adalah kekuatan otot secara spesifik. Dari penelitian ini ditemukan observasi bahwa indeks massa tubuh menjadi salah satu faktor independen untuk melihat kualitas dari otot.

\section{Pengaruh contrast bath terhadap pemulihan kekuatan otot pada pemain futsal}

Dari hasil penelitian dapat disimpulkan bahwa ada perbandingan pengaruh contrast bath terhadap pemulihan kekuatan otot pada pemain futsal SMA Kota Malang. Contrast bath merupakan modalitas termal dimana bagian tubuh direndam secara bergantian dalam air panas dan air dingin untuk suhu, waktu dan durasi untuk meningkatkan kekuatan otot, mengurangi nyeri otot, menyembuhkan kerusakan otot (Bieuzen $e t$ al, 2013). Penelitian yang dilakukan oleh Wisnuaji et al (2017) menunjukkan efek pemberian contrast bath dapat menyebabkan penurunan asam laktat dengan proses vasokontriksi dan 
vasodilatasi. Fase vasokontriksi akan menyebabkan menurunnya metabolisme lokal untuk menghambat akumulasi asam laktat sehingga spasme otot akan menurun. Fase vasodilatasi akan menyebabkan peningkatan aliran darah sehingga tersedia jumlah oksigen yang cukup agar sisa metabolik cepat menurun yang memberikan efek positif pada elastisitas otot. Dari proses pembersihan, metabolik akan didaur ulang dan menghasilkan asetil COA, dari asetil COA terbentuk sumber energi (ATP) yang dipergunakan untuk kekuatan otot (Norlinta, 2013). Sayers et al (2011), dalam penelitiannya yang membandingkan pemulihan aktif, pemulihan pasif, dan contrast bath, didapatkan kesimpulan bahwa contrast bath lebih efektif daripada pemulihan pasif dan pemulihan aktif dalam pemulihan pada atlet terutama pada saat mengikuti perlombaan atau pelatihan dengan periode pemulihan yang terbatas.

\section{Pengaruh ice bath terhadap pemulihan kekuatan otot pada pemain futsal SMA Kota Malang.}

Dari hasil penelitian diperoleh kesimpulan bahwa ada perbandingan pengaruh ice bath terhadap pemulihan kekuatan otot pada pemain futsal SMA Kota Malang. Menurut Elias et al (2012), ice bath dapat memulihkan kinerja fisik, meningkatkan kekuatan otot dan mengurangi nyeri otot. Perendaman air dingin akan menginduksi vasokonstriksi perifer (Peiffer et al, 2009). Vasokontriksi ini dapat mengurangi permeabilitas pembuluh kapiler, seluler dan limfatik dan akan mencegah pembengkakan dari difusi cairan (Eston \& Peters, 1999), sehingga membatasi respon inflamasi akut setelah kerusakan otot akibat latihan. Selain itu, ice bath dapat mengurangi nyeri, relaksasi otot, relaksasi psikologi, menghambat kerusakan otot, mengurangi edema dan menurunkan suhu jaringan (Rifan, 2014).

$\begin{array}{rrr}\text { Secara } & \text { fisiologis, } & \begin{array}{r}\text { metode } \\ \text { cryotherapy }\end{array} \\ \text { menyebabkan } & \text { terjadinya }\end{array}$

vasokontriksi arteriola dan venula secara lokal. Vasokontriksi ini disebabkan oleh aksi reflek dari otot polos yang timbul akibat stimulasi sistem saraf otonom dan pelepasan epinehrin dan norepinephrin. Walaupun demikian apabila dingin tersebut terus diberikan selama 15 sampai dengan 30 menit akan timbul fase vasodilatasi yang terjadi intermiten selama 4 sampai 6 menit. Periode ini dikenal sebagai respon hunting. Respon hunting terjadi untuk mencegah terjadinya kerusakan jaringan akibat dari jaringan mengalami anoxia jaringan (Arovah, 2010). Dalam keadaan dingin, hipotalamus akan mengatur otot rangka untuk vasokonstriksi secara aktif. Hal ini akan menyebabkan seseorang mengigil dan meningkatkan suhu badan. Pada saat yang sama, kelenjar adrenal akan mensekresikan hormon adrenalin dan nonadrenalin, adapun tiroid akan mensekresikan hormon tiroksin, semua hormon ini bertujuan untuk meningkatkan suhu badan dengan cara meningkatkan metabolisme tubuh. Meningkatnya suhu dalam tubuh membuat peredaran darah menjadi lancar sehingga suplai glukosa dan oksigen dalam otot terpenuhi untuk proses energi, sehingga akan membantu proses pemulihan kelelahan otot yang akan berdampak pada kekuatan otot (Rifan, 2014).

Ascensao et al, (2011) mengatakan bahwa setelah pertandingan, para pemain di kedua kelompok menunjukkan peningkatan aktivitas kreatin kinase plasma (30 menit, 24 jam, 48 jam), mioglobin (30 menit) dan konsentrasi protein C-reaktif (30 menit, 24 jam). Terjadi penurunan kemampuan peak jump dan kekuatan otot dan terjadi peningkatan DOMS setelah pertandingan. Hasilnya menunjukkan bahwa perendaman air dingin segera setelah pertandingan sepak bola satu kali mengurangi kerusakan otot, meningkatkan kekuatan otot, dan meningkatkan kemampuan peak jump. Menurut Delextrat et al, (2012), mengatakan dalam penelitiannya yang membandingkan efek intermiten 
perendaman air dingin dan pijat pada persepsi dan kinerja penanda pemulihan oleh pemain basket setelah pertandingan kompetitif. Didapatkan hasil bahwa perendaman air dingin lebih berguna daripada pijat dalam pemulihan dari pertandingan basket, terutama pada wanita.

\section{Perbandingan pengaruh contrast bath dan ice bath terhadap pemulihan kekuatan otot pada pemain futsal SMA Kota Malang.}

Pada penelitian ini didapatkan hasil tidak terdapat perbedaan pengaruh contrast bath dan ice bath pada pemulihan otot pemain futsal SMA. Kedua intervensi memiliki efektivitas mempercepat pemulihan otot yang sama. Perendaman contrast bath dan ice bath memiliki prinsip menyebabkan vasokonstriksi dan vasodilatasi yang berdampak pada kelancarkan pembuluh darah, peningkatan proses metabolisme dalam tubuh, melancarkan suplai oksigen dan glukosa, sehingga terbentuk sumber energi (ATP) yang akan dipergunakan untuk menghasilkan kekuatan otot.

Vaile et al, (2008), dalam penelitiannya yang menguji efek dari tiga intervensi hidroterapi pada gejala fisiologis dan fungsional dari nyeri otot onset tertunda (DOMS). Untuk setiap percobaan, subjek melakukan protokol pers kaki yang menginduksi DOMS diikuti oleh pemulihan pasif (PAS) atau salah satu intervensi hidroterapi selama 14 menit. Lompat squat, squat isometrik, nyeri yang dirasakan, lingkar paha dan variabel darah diukur sebelum, segera setelah, dan pada 24, 48 dan 72 jam setelah latihan. Secara keseluruhan, Cold Water Immersion (CWI) dan Contrast Water Therapy (CWT) ditemukan efektif dalam mengurangi defisit fisiologis dan fungsional yang terkait dengan DOMS, termasuk perbaikan pemulihan kekuatan isometrik dan daya dinamis dan pengurangan edema lokal. Sementara Hot Water Immersion (HWI) dan pemulihan pasif (PAS) tidak efektif untuk pemulihan semua gejala fisiologis dan fungsional.

Higgins (2012) dalam penelitiannya yang mengevaluasi hidroterapi sebagai strategi pemulihan setelah permainan simulasi rugby union dan satu minggu pemulihan dan pelatihan, dengan variabel dependen antara evaluasi dua game simulasi rugby union. kesimpulan, dalam penelitian ini menunjukkan bahwa ice bath dan contrast bath lebih menguntungkan bagi pemulihan atlet dari olahraga tim daripada istirahat pasif dalam permainan rugby union berturut-turut.

\section{KESIMPULAN}

Tidak terdapat perbedaan pengaruh pemberian contrast bath dan ice bath pada pemulihan kekuatan otot pemain futsal setelah pertandingan.

\section{DAFTAR PUSTAKA}

Allen, D., Lannergren, J., \& Westerblad, H. (1995). "Muscle Cell Function During Prolonged Activity: Cellular Mechanisms of Fatigue". Experimental Physiology, 80, 497527.

Al Fajr, Faldy Akbar (2019). "Profil

Kondisi Fisik Peserta

Ekstrakulikuler Bulu Tangkis di SMA Negeri 3 Klaten”. Skripsi. Fakultas Ilmu Keolahragaan. Yogyakarta

Anggoro, A. S. (2015). "Hubungan Antara Kekuatan otot Quadriceps Femoris Terhadap Kecepatan Berjalan pada Lanjut Usia di Posyandu Dahlia Boyolali". Skripsi. Fakultas Ilmu Kesehatan. Surakarta.

Arovah, N. I. (2010). "Terapi Dingin (cold therapy) dalam Penanganan Cedera Olahraga". Skripsi. Fakultas Ilmu Keolahragaan. Yogyakarta.

Ascensao, A., Leite, M., Rebelo, A. N., Magalhaes, S., \& Magalhaes., J. (2011). "Effect Of Cold Water 
Immersion On The Recovery of

Physical Performance And Muscle Damage Following A

One Off Soccer Match".

Journal of Sport Sciences, 29, 217-225.

Bieuzen, F., Bleakley, C. M., \& Costello, J.

T. (2013). "Contrast Water Therapy and Exercise Induced Muscle Damage : A Systematic Review and MetaAnalysis".PLoS ONE, 8, 1-15.

Delextrat, A., Gonzalez, J. C., Hippocrate, A., \& Clarke, N. D. (2013). "Effect Of Sport Massage And Intermitten Cold Water Immersion On Recovery From Matches By Basketball Players". Journal of sport sciences, 31, 11-19.

Elias, G, P., Varley, M. C., Wyckelsma, V. L., Mckenna, M. J., Minahan, C. L., et al. (2012). "Effect of Water Immersion on Posttraining recovery in Australian Footballers". International Journal of Sports Physiology and Performance, 7, 357-366.

Eston, Roger \& Peters, Daniel. (1999). Effects of cold water immersion on the symptoms of exerciseinduced muscle damage. Journal of sports sciences. 17. 231-8.

Greig, M., Small, K., Mcnaughton, L., \& Lovell, R. (2010). "The Effects of Multidirectional Soccer Specific Fatigue on Markers of Hamstring Injury Risk". Journal of sciece and medicine in sport, 13, 120-125.

Higgins, T.R., Cameron, M., Climstein, M. (2012). "Evaluation of Hydrotherapy, Using Passive Test and Power Test, For Recovery Acroos A Cyclic Week of Competitive Rugby Union". Journal of
Strength and Conditioning

Research, 27, 954-

965.

Ingram, J; Dawson, $\mathrm{B}$; Goodman, $\mathrm{C}$; Wallman, et al. (2009). Effect Of Water Immersion Methods On Post-Exercise Recovery From Simulated Team Sport Exercise. Journal of science and medicine in sport, vol. 12 hal. 417-421.

Izzuddin, F. I. (2018). "Perbandingan Contrast Bath dengan Ice Bath Terhadap Pemulihan Agility pada Pemain UKM Sepak Bola Universitas Muhammadiyah Malang". Skripsi. Fakultas Ilmu Kesehatan. Malang.

Kim,JinHong, Jung, HyunKyung, Yim, JongEun. (2020). Effects of Contrast Therapy Using Infrared and Cryotherapy as Compared with Contrast Bath Therapy on Blood Flow, muscle Tone and Pain Threshold in Young Healthy Adults. Med Sci Monit.26

Miyatake, N., Miyachi, M., Tabata, I., Sakano, N., Hirao, T., et al. (2012). "Relationship Between Muscle Strength and Anthropometric, Body Composition Parameters in Japanese adolescents". Journal Health, 4, 1-5

Murhananto. (2008). "Dasar-Dasar Permainan Futsal". Jakarta: Kawan Pustaka.

Ningrum, N. A., Ekawati., \& Widjasena, B. (2017). "Hubungan Indeks Massa Tubuh dan Kekuatan otot kaki Dengan Keluhan Nyeri Otot Kaki Pada Buruh Angkut Barang (Porter) Di Stasiun Kereta Api Pasar Senen Kota Jakarta". Jurnal Kesehatan Masyarakat, 5, 273-280.

Norlinta, S. N. O. (2013). "Pengaruh Penambahan Contrast Bath Pada Colling Down Terhadap 
Pemulihan Kelincahan Atlet setelah latihan zig zag run". Skripsi. Fakultas Ilmu Kesehatan. Surakarta.

Oliver, J., Armstrong, N., \& Williams, C. (2007). "Change in Jump Performance and Muscle Activity Following Soccer Specific Exercise". Journal of sports science, 26, 141-148.

Peiffer, Jeremiah \& Abbiss, Chris \& Nosaka, Kazunori \& Peake, Jonathan \& Laursen, Paul. (2008). Effect of cold water immersion after exercise in the heat on muscle function, body temperatures, and vessel diameter. Journal of science and medicine in sport / Sports Medicine Australia. 12. 91-6

Rifan, M. (2014). "Efek Cryotherapy (water immersion) Terhadap Pemulihan Kelelahan Atlet Sepakbola". Skripsi.

Fakultas Ilmu

Keolahragaan. Yogyakarta.

Robineau, J., Lacroix, M., Jouaux, T., \& Babault, N. (2012).

"Neuromuscular Fatigue Induce By A 90 Minute Soccer Game Modeling". The journal of Strength and Conditioning Research, 26, 555-562.

Sayers, Mark \& Calder, Angela \& Sanders, Jo. (2011). Effect of whole-body contrast-water therapy on recovery from intense exercise of short duration. European Journal of Sport Science. 11. 293-302

Sayono. (2011). Biokimia Otot. Yogayakarta : Nuha Medika

Setiowati, A. (2014). "Hubungan Indeks Massa Tubuh, Persen Lemak Tubuh, Asupan Zat Gizi Dengan Kekuatan Otot”. Jurnal Media Ilmu Keolahragaan Indonesia,
4, 32-38.

Simon, E. (2017). "Pengaruh Pemberian

Vitamin B Kompleks Terhadap

Penurunan Asam Laktat Setelah

Melakukan Lari Sprint 100

Meter Mahasiswa Ilmu

Keolahragaan Universitas

Negeri Medan”. Skripsi.

Fakultas Ilmu Keolahragaan.

Medan.

Vaile, J., Gill, N. D., \& Blazevich, A. J. (2007). "The Effect Of Contrast Water Therapy On Symptoms Of Delayed Onset Muscle Soreness". Journal of Strength and Conditioning Association, 21, 697-702

Vaile, J., Halson, S., Gill, N. D., \& Dawson,B. (2008). "Effect Of Hydrotherapy On The Signs And Symptoms Of Delayed Onset Muscle Soreness". Europian Journal of Applied Physiology, 102, 447-455.

Valenzuela, P.L., Maffiuletti, N.A., Tringali, G. et al. (2020).Obesity-associated poor muscle quality: prevalence and association with age, sex, and body mass index. $B M C$ Musculoskelet Disord. 21, 200.

Wasisto, H. B. (2016). "Perbandingan Kekuatan Otot Tungkai Pada Atlet Usia Remaja Cabang Olahraga Taekwondo Nomor Poomsae Dan Kyarugi Di kota Semarang. Skripsi. Fakultas Kedokteran. Semarang.

Windiyatno, A. (2015). Perkembangan Kekuatan Otot Tungkai, Kekuatan Otot Lengan dan Ketahanan Cardiovaskuler Pada Adolesensi Usia 13-18 Tahun Ditinjau Dari Jenis Kelamin Dan Ketinggian Wilayah Tempat Tinggal (Studi Krosseksional Pada Pelajar SMP dan SMA Di Daerah Kabupaten P. Thesis. FIK UNS. Surakarta 
Wisnuaji, A., Doewes, M., Siswandari, S. (2017). The Differences of The Effects On VO2MAX-Based Recovery Method Of Post
Anaerobic Interval Training To Lactic Acid Levels. Europian Journal of Physical Education and Sport Science.3 